\title{
Umwelt and Circumstance
}

Olive Perez A*

Personal, Spain

*Corresponding author: Alfonso Olivé-Pérez, li Avenir 3508021 Barcelona, Spain, Tel: +34 609377407; Email: 4728aop@comb.cat
Investigation Paper

Volume 3 Issue 1

Received Date: January 10, 2020

Published Date: January 30, 2020

DOI: $10.23880 /$ phij-16000137
In the Orteguian studies there is a surprising fact: no author - if we except Benavides, Cela or Atencia - have pointed out the influence of Jacob von Uexküll in Ortega's work. In the Prologue of the Spiritual edition of Ideas for a biological conception of the world, Ortega writes:

"[Referred to Uexküll ] I must state that these biological meditations have been exercised on me since 1913."

In 1934, the Preface to German (OC IX, p. 161 ${ }^{1}$ ):

"Hence the series of essays written by me during those years, when extending von Uexküll's biological ideas to the philosophical order, I combine the idea of man living in the mudio."

My purpose is to show that one of the key findings of Oretegam the circumstance, comes from the Umwelt of the Estonian-German biologist

\section{The concept of Umwelt in Uexküll}

The Umwwelt is a fundamental discovery of Uexküll to establish the difference between Umgebung - physical and geographical environment - and Welt, world or universe of science (Heredia, 2014, page 22). The concept of Umwelt designates the construction of a world of its own for each animal, a perceptive world, Merkwelt, typical of the living, such that, in a single physical and geographical world, there are infinite perceptual worlds inhabited each one for the living that has built them and in which he is perfectly adapted.

Although the fundamental concept for the biologist is the Bauplan or functional plan: The living person has his parts ordered according to a construction plan, including his receivers. Therefore, as we shall see, this functional plan is essential for the construction of the Umwelt.

1 All quotes from Ortega come from the Complete Works Edition of Editorial Taurus, Madrid. Employment $O C$ and the volume in Roman numerals, followed by the page).
Merkwelt is a world built by the living, as I will explain below, it is a real world, it is a mole, it is the place that the living can know, the place where he can act: seek food and reproduce. It is not a "ghost world", it is not a "phenomenal world", it is for the living a real world.

For the biologist, each living person has receptors sensory organs whose structure depends on the "construction plan" - capable of capturing notes from the world around $\mathrm{him}^{2}$. Some notes that reach the receivers cannot be processed, that is, they do not affect him vitally, others are beneficial and others are harmful. Ortega expresses this effect with the image of the sieve, present in the Theme of our time, which lets pass those things of the world that interest us vitally and rejects the others. However, the Orteguian sieve is not only physical, it is also psychological.

The stimuli generated in the receptors pass, through the nervous system, to the central organ, which, depending on the stimulus and internal processes, - Innerwelt - generates an effector response, acting on the muscular motor plate ${ }^{3}$.

2 In this sense it is interesting to note that the living person does not have direct contact with the objects of the Umgebung, he only has it with the perceptual notes that come from such objects and that are vitally interesting for each living being. The living being captures the sensory notes, transmits them to his nervous system and with the help of the schemes - nervous networks - of space and time, together with those of form, in the superior animals, he constructs each and every one of the objects that They constitute his Merckwelt . For this reason, each living person has his exclusive Umwelt. It is significant that lower animals - non-brain possessors - have a Umwelt lacking forms. As of 1930, the Orteguian Circumstance will also be devoid of forms, in the physical sense of the term.

3 These muscle stimuli produce the responses of the living, within their world of effects, Wirkungwelt. Unlike Merkwelt, the world of effects is not absolutely specific species: different species can exert their characteristic responses in the same moles. The physical space of the world of the effects of a species - for example, the starfish - interconnects with the physical space where another species performs its effects - for example, the sea urchin. Each has its own perceptive world and its repertoire of actions that constitute its world of effects, although in this case it is carried out in a common physical space that allows interaction between species. If it were not this way, if each species had its own exclusive space of effects, the lion 


\section{Philosophy International Journal}

In this way, the organism builds two worlds, the world of stimuli and the world of responses, and both, together with the animal, constitute the fundamental unit that studies biology. These worlds - sensory world and world of effects - form the "surrounding world" of the living. Such a world, own and exclusive to each living, has its own space and its own time. This is extensible to man:" each man is surrounded by a world <<appropriate $>>$ to him or accommodated to him ${ }^{4}$, which we call $<<$ surrounding world $>>$ " .

The biologist himself clarifies the topic: "To designate this world, which is the product of the organism, I have tried to introduce the word Umwelt (surrounding world.)"'.

"For every animal there is a special world, which is composed of the distinctive notes collected by him from the outside world,"7 that is, each animal, through the senses, captures a portion of the world and this world, which depends on what it finds in the outside world and on the structure of the animal's receptors ${ }^{8}$ - which harmonize ${ }^{9}$, by definition, with the rest of the living according to the "construction plan," thus constructing, the "surrounding world".

Cassirer ${ }^{10}$ agrees with the above about the importance of the "construction plan" and points out the importance of the receivers and the "functional circle in the construction of the Umwelt ${ }^{11}$. The recipients, according to the structure determined by the plan, capture some stimuli from the

could not eat the gazelle or the cat with the mouse.

4 Cowboy, Moya F, Randall CB, Gomez C (1991) 433-442 say that Uexküll introduces in biology a very concrete meaning for the concept of "medium", being understood as the totality of the conditions that assure a living being to be conserved in accordance with its specific organization. This is equivalent to Uexküll's assertion that the living being is fully adapted, so the evolution for survival of the fittest is meaningless: all living are equally fit. According to K. KULL ("Uexküll and the post- modern evolutionism", Sing Systems Studies, $32,2004,99-113$ ) for Uexküll, evolution was not a necessary condition for constructing a theory of the living.

5 von uexküll, 1913 Bausteine p. 40.

6 Op cit, p. 52.

7 Op cit, p. 53.

8 Lange FA, in his History of Materialism, had already pointed out that the Merckwelt, "perceptual world" was subject to the type of organization of the living being (Quoted by P. Martínez "Nietzsche and organic hermeneutics" Veritas, III, 2008, 331-342).

9 "The body distinguishes itself from all inorganic products in that it has a functional plan, that is, in it, all the various parts are arranged in such a way that their functions are linked to each other according to plan, and from this mode facilitate the total function of the organism". (Uexküll, Bausteine, p. 49). The idea is of Kantian origin.

10 Cassirer The problems of knowledge, Op cit, p. 245.

11 As of 1928, the "plan" ceases to be the cornerstone of the Uexküll system to be replaced by the "functional cycle", which would be responsible for the existence and maintenance of the "plan", including the operation mobile. outside world and ignore other stimuli. These stimuli captured, through the "functional circle" generate the effector responses[12] ${ }^{12}$. The "surrounding world" (Umwelt) results from the union of the perceptual world (Merkwelt ) and the world of effects (Wirkungwelt) and both are a function of the animal's construction plan. The biological unit is the animal with the surrounding world. And so, Uexküll says: "If you want to embrace the world of effects and the perceptual world with the name of the surrounding world, it may well be done; but one must take into account immediately that the two together do not result in any unity, but for that the organism of the animal is essential, which is the one that creates the dependence between both worlds ${ }^{\prime 23}$. And, in 1920, he wrote: "Now we can consider each animal as a unit with its surrounding world"14.

The author especially insists on the perceptual world: "each animal has its own perceptual world, composed of objects different from the others ${ }^{\prime 15}$. Now, it is essential to understand that the animal that captures are the perceptual notes that come from the objects that surround it and, consequently, does not know the object itself ${ }^{16}$, know the perceptual notes ${ }^{17}$. With the multiple perceptual notes obtained by its receivers, it constructs the objects. "More why is it necessary to convince ourselves so deeply and deeply, of the fact that all the objects

12 von Uexküll T, "A theory da Umwelt de Jakob von Uexküll” Galaxia, 7, 2004, 19-48, says that one of the presuppositions of his father's doctrine was the unity of the vital process - that is, the life was expressed uniformly from the amoeba to man. According to this author, Uexküll understood the "vital process" as a coherent system in which the subject and the object are defined as interrelated elements in a larger whole. Uexküll rejected - says his son - both idealistic positivism and relativism, such that, philosophically he followed Kant, although, possessing a concept of natural philosophy of a romantic nature, in harmony with Schelling - whose philosophy of nature approaches that of Goethe whose influence on Ortega I have discussed above - as well as the physiologist J. Müller attached to the Naturphilosophie - and von Baer, the most important embryologist of the nineteenth century, a defender of a "specific life energy", within an atmosphere close to Kantian natural philosophy. This conception of the subject and the object, always according to T. von Uexküll, generates another basic assumption, time as a rhythm or structure of the vital process, such that the experience of time differs from one species to another - remembering Bergson - which suffers the influences coming from the external world, or automatic, specific to each species.

13 von Uexküll J, Bausteine, p. 53.

14 von Uexküll J.Biological letters to a lady, Op cit, p. 77.

15 Bausteine, p. 170.

16 Tønnessen $\mathrm{M}$ in "Umwelt transitions: Uexküll and enviromeental change", Biosemiotics, 2, 2009, 47-64 considers that Uexküll, unlike Kant questions the existence of a phenomenal reality when considering that animals do not Humans have a perceptual world like humans. The problem is that Uexküll does not accept studies of animal psychology and doubts the existence of non-human minds, so the construction process, although similar to Kantian, presents great differences.

17 Nietzsche F Writings on rhetoric, (translation LE from Santiago), Editorial Trotta, Madrid, 2000, p. 92 says "Instead of the thing, the sensation picks up a signal." 


\section{Philosophy International Journal}

that surround us consist of impressions of the senses arranged by schemes of both space and time??"18 and adds: "The sum of these stimuli forms the animal's surrounding world ${ }^{19}$ : each animal lives in a special world ${ }^{20}$ arranged for him"121. It should be noted again that there can be and indeed there are, worlds of the effects of various animal species that intersect with the worlds of the effects of other animals ${ }^{22}$, because, just like that, the explanation of the interaction of the starfish with the crab or the oyster is understandable, even though its perceptual worlds are different ${ }^{23}$.

We must ask why each animal accepts some stimuli and rejects others. A first answer is that it depends on the structure of its receptors. It is possible, however, to consider what this structure depends on. We will respond firstly that it depends on the "construction plan". And we insist on what does the "construction plan depend on? As we have pointed out, Uexküll hesitated for some time considering that non-physical factors could exist. In 1910 he published an article under the title "Mendelism", which is included in

\section{8 von Uexküll J Bausteine, p. 41.}

19 The Umwelt is not a paradise. J. Marías Ortega, circumstance and vocation, $O p$ cit, p. 131, notes, following Uexküll, that the Umwelt contains harmful elements, as well as usable elements. Ortega will say, after the second crisis, that circumstances have favorable, unfavorable and neutral elements. Thus, in Meditations of our time, in 1928, OC, VIII, p. 41, he says that to live is to be in the world. The world where we live is made up of pleasant and unpleasant things.

20 It is interesting to understand that the point of view adopted by Uexküll is the point of view of the animal and not of man, which makes the world that is familiar to us disappear, the world with sky and earth, with sun and stars, and this makes it appear "a new world, completely different from ours, its Umwelt" (in Umwelt und Innerwelt der Tiere, Op cit, p. 6). And " The Umwelt of the paramecium is limited to two things: liquid without stimulus and liquid with stimulus, where the stimulus can be chemical or mechanical" Op cit. p. 47 and in Bausteine offers us the description of the Umwelt of the starfish, sea urchin, dragonfly or jellyfish, while in a work published in Revista de Occidente, The Biology of the Jacobean Oyster, Op cit. He speaks of the Umwelt of said mollusk. The comparison of all these surrounding worlds draws a universe totally alien to the human universe and absolutely different worlds for each species.

\section{Bausteine, p. 31.}

22 This intersection opens the door to the possibility of evolution, of course not Darwinian. V. Castle "Order, limits and transgressions. Reflections on the work of Jakob von Uexküll" Philosophical signs, XIV, 2012, 91-111 indicates that Uexküll accepted in 1920 that the medium could modify the "construction plan", but always under the guidance of a plan and maintaining its coordination with the environment and without development or progress, since it considers the creation itself perfect. (page 101-102) There is no chance, everything happens by necessity, including the precise mechanisms to prevent the excessive spread of a species (p. 104). K. Kull, Op cit, 2004, p. 107, cites a text by T. von Uexküll in which he insists that there can be no linear evolution of an adaptive nature, since Umwelt and harmony among the living must be taken into account. (Uexküll speaks of the harmony between the parts of the living and of these among themselves that constitutes a universal harmony). Evolution can lead to varying degrees of complexity, but always with the same perfection and maintaining the harmony of the universe.

23 Op cit, p. 54. the fourth part of Bausteine. In it he appreciates a solution line: genes would be responsible for the "construction plan". This seems to be contradictory with its anti-mechanicism. Actually, as Heredia shows ${ }^{24}$, what is inherited, or what the "genes" determine, is a predisposition, not a mechanical response. Under such conditions, the different features of the world are partially prefigured by such predispositions. In this sense, Uexküll writes: "What is the factor that gives the living protoplasm the necessary impulse for the formation of differentiated organs? Today you answer that, it's the genes" 25 . And in later pages he develops a theory of the role of genes in the formation of the various organs that, probably, would not be subscribed today by anyone, but which is undoubtedly far superior to the one proposed by Darwin ${ }^{26}$, which allows him to overcome the forces vitarles type of Entelequia of Driesch or proposed by Von Baer.

What interests us about all of the above? First, that each living person has his own surrounding world ${ }^{27}$; such a world is the result of what the world is like and what the living plan is and its vital interests: with the notes perceived by the different receptors - organs of the senses - your nervous system creates an image ${ }^{28}$ of the world, which is characteristic of each living being and finally, the inseparability of the surrounding and living world. Another interesting point in

24 Heredia JM "Animal ethology, ontology and biopolitics in Jakob von Uexküll" Philosophy and History of Biology, 6, 2011, p. 69-84.

\section{Op cit, p. 145.}

26 By 1920-1928 he accepted a certain evolution of a saltationist nature, without intermediate species, of the type proposed by de Vries, although with the character indicated above. Ortega will echo her.

27 Vela F "The individual and his environment", Revista de Occidente, 1, 1923.95-105, shows the interest of the Ortega group in our biologist. Vela, an intimate collaborator of Ortega and secretary of the Magazine of the West, includes this work in the first issue of the magazine, where he says that each animal has its own perceptual world built through discrimination between the stimuli that reach its receptors, which, although Vela does not indicate it, have a structure that is in accordance with the plan. Consequently, the fundamental concept of Uexküll is "the plan", although the concept of greatest philosophical interest is the Umwelt.

28 In Bausteine, p. 202, he says "Antimony (probably I should say, antimundo) is the one who, in the higher animals, inhabits the perceptible world of objects." He has previously explained that higher animals possess "mirror" neurons that, in some way, reflect the world, creating an antimundo, copy-it is assumed, more or less appropriate according to the animal-of the external world. Uexküll writes: "This organ resembles a mirror, the only device that is also proper to reproduce the outside world. But the mirror is a physical instrument that, without distinction, reproduces all forms. In the receiving organ, a mirrored physical world does not become alive, but a biological antimundo. In this there is only a selection of those forms that are important for the life of the animal." Op cit, p. 201. This clarifies the antimundo. However, it should be noted that these biological mirrors have nothing to do with modern "mirror neurons" and that the "reflecting" forms are constructions built on sensory impressions, since "a group of sensations ordered with help of a scheme is an object", ICBM, page 124 (see also p. 32 and p. 77). A more extensive and complete description of the living relationship with the environment and the role of the nervous system is done by Uexküll in Theory of Life, Op cit, p. 77 et seq. 


\section{Philosophy International Journal}

Uexküll's conception is that the living ceases to be seen as an isolated being and is seen as associated with his own world, the minimum unit of biological analysis is living-associated world. However, according to Uexküll, each living person is a subject ${ }^{29}$ and everything he knows is in our Umwelt, in his perceptual world, the subject / object dichotomy is broken: both are integrated into a single unit. We will find this aspect in Ortega with the dii consentes ${ }^{30}$.

In Umwelt und Innerwelt der Tiere, 1909, Uexküll limited the surrounding world to the animal world, especially lower animals, however, in Ideas for a biological conception of the world, it extends to the human being. And, therefore, it is worth saying: "Every man is surrounded by a world suited to him, called his surrounding world"31. And also: "What is valid for all animals is also valid for man. He too is locked into a perceptual world corresponding to his abilities" ${ }^{32}$. "The assumption that all men live in the same world is a neverexhausted source of the most serious mistakes and mistakes"133. We have seen this last idea expressed in Don Quixote at school in reference to the children's world.

The surrounding world of Uexküll is, as I have indicated above, a moles, a place: "our perceptible world forms only a modest section of the outside world"34, it is not an ideal world, it is not an imaginary world: it is a real world, a fragment, a portion of the entire real world. In this way, and applying it to man, the Estonian biologist can write: "The normal perceptual world of man in free Nature shows him a field of effects limited all around the horizon. This horizon will be rare that it is beyond six hours of road"35. The surrounding world, both of man, and of the animal is a physical, geographical world, a moles, a place, a physical environment. That is why the author adds: "Therefore, man can in one day reach that limit and return from it. The territory closed by the horizon is its homeland, which you can travel on foot in its entirety without having to spend the night outside $i t^{\prime \prime 36}$. No human being can walk through an ideal space, therefore, the "perceptual world", a section of the Umwelt, is a physical

29 Nietzsche (Quoted by P. Martínez Op cit, p. 336) previously developed this same idea: The living being "chooses" the stimuli according to their way of feeling, each animal has a way of being subject and a way of knowing, which have become according to growth criteria and their way of life.

30 Olivé Pérez A "José Ortega y Gasset and the philosophy of life" Essays in philosophy, 3, 1 semester, 2016, http://www.ensayos-filosofia.es/ archivos/articulo/jose-ortega- and-gasset-and-life-philosophy? _kw_id = M3wyMDE2fDE\% 3D \&_kw_number $=15$.

31 Bausteine, p. 40.

32 Bausteine, p. 116.

33 Bausteine, p. 220

34 Baustrine, p. 115

35 Bausteine, p. 116.

36 Ibidem. world and, as in man coincides the perceptual world and the world of effects, the Umwelt, whether animal or human, has a physical character. And, Ortega's circumstance, as I will show later, also has a physical character, unlike Husserl's.

\section{The Conception of the Circumstance before Quijote Meditations ${ }^{37}$}

Julian Marias ${ }^{38}$ emphatically states that the notion of "circumstance" does not come from biology and therefore, even less from Uexküll. The reasons for this would be of two types: historical ones: before Ortega could read Uexküll he had already spoken about the circumstances; the other reasons are philosophical in nature and refer both to the content of this notion, and to its relationship with culture.

Morón Arroyo ${ }^{39}$ relates the "circumstance" in the Quijote Meditations with phenomenology and with Husserl. Circumstances are the possible aspects of spontaneous life that, using a phenomenological method, can describe its essence and relate it to Scheler's scale of values ${ }^{40}$.

Cherry tree ${ }^{41}$ also links the Orteguian circumstance to Husserl and indicates that the previous texts - Adam in Paradise and Vejamen of the speaker - they belong to the neo-Kantian era - with which I fully agree - and in them there is no trace of what will be The theory of circumstance.

For S. Rábade $\mathrm{e}^{42}$ the circumstance is our material and social contour, it is an ingredient of our life ${ }^{43}$. Although, in principle, I could agree with him in his interpretation of the notion we study, however, I do not believe that this author accepted that Ortega is using a biological matrix from Uexküll

37 It is necessary to clarify that Ortega never writes Umwelt. In the Spanish translation of 1 Bausteine, published under the direction of Ortega, there is a footnote on page in página53, indicating that the surrounding world could be translated into Spanish as "picture" or "contour". Ortega speaks interchangeably of "circumstance", "surrounding world", "around world", "panorama", "landscape". He does it in different and sometimes in the same text, so he seems to consider them synonyms.

38 Marïas Ortega J, circumstance and vocation, Op cit, p. 159.

39 Morón C The Ortega y Gasset system, Op cit, p. 143-146.

40 It is interesting to note that for Morón, the same as for $\mathrm{Ph}$. W. Silver Phenomenology and vital reason. Genesis of "Meditations of Don Quixote" by Ortega y Gasset. (Translation C. Thiebaut) Editorial Alliance, Madrid, 1978, the influence of Scheler is fundamental and, in the case of Morón, Scheler is the model of both the notion of circumstance and the notion of perspective, at least in the latter case, in Quijote Meditations. I have previously pointed out Scheler's influence, both in the conception of life and in Ortegu's knowledge of von Uexküll's work.

41 Cerezo $\mathrm{P}$ The will to adventure, Op cit, page 224.

42 Rábade S Ortega y Gasset, philosopher, man, knowledge and truth, Op cit, p. 92.

43 Rábade's study focuses on this theory in the work Around Galileo, without commenting at all the works of the period we are investigating. 


\section{Philosophy International Journal}

in order to develop a philosophical conception of the Umwelt, in the same way that Scheler had done in The Formalism in Ethics, 1913. Or more clearly said: Ortega takes a biological concept and fills it with a philosophical content that allows him to overcome the individualism of neo-Kantian idealism.

If we return to J. Marías, who is the referent of a large number of authors, and leaving later to consider his second argument, I am interested in studying if, as this author says, the "circumstance" is found in texts from 1910, Adam in paradise, and from 1911, Vejamen of the speaker. Although it is not impossible that Ortega had already read, before writing both texts, Umwelt und Innerwelt der Tiere, which, as I have indicated, I do not think had happened, should have been able to extrapolate the Umwelt from the animal world to man, fact that Uexküll had not yet done. Ortega, however, could have read both Bergson and Driesch, although at that time and under the neo-Kantian influence, I doubt they could influence him.

Focusing on the first cited work $^{44}$, we observe that, for Ortega, Paradise is a geographical place: Paradise "falls through Padam - Aram, as it goes from Tigris to Euphrates" ${ }^{\prime 4}$. Perhaps for Marias, the circumstance is expressed in the phrase: "What, then, is Adam, with the vegetable of Paradise around, surrounded by animals, there, in the distance, the rivers with their restless fish and more there the mountains of petrefact bellies, and then the seas and other lands, and the Earth and the worlds? ${ }^{46}$. "This quote, I think, has little to do with a "surrounding world," with the "circumstance." Ortega is describing the world, the entire Earth. Conscious life is born with Adam, life surrounded by a nature that begins to exist when Adam does. "[Paradise] is the ubiquitous scenario for the immense tragedy of life" ${ }^{\prime \prime 7}$. Paradise is the ubiquitous scenario, that is, what is found everywhere. It is not, then, the world around, it is not "my surrounding world", it is everything, it is the Earth, as Ortega indicates. If this is so, as I believe, Adam in Paradise cannot be seen as antecedent, as an element of the supposed prehistory of the circumstance whose only prehistory is found in the elaboration of the Umwelt by Von Uexküll.

The second text is much more vague. It's about Speaker's Vejamen ${ }^{48}$ where we can read: "Because the speaker is always who is aware of the circumstances. More what are the circumstances? Are these only one hundred people, these fifty minutes, this small matter? Every circumstance is embedded in a wider one; Why think that only ten meters of space surround me? And those around these ten meters? Grave oblivion. Miserable awkwardness, not taking over but a few circumstances, when in truth everything surrounds us !9 "The $^{49}$ long quote clearly expresses that it does not speak at all of the surrounding world, on the contrary it refuses to focus only on the surrounding world ${ }^{50}$.

\section{The Conception of the Circumstance in Quijote Meditations}

In 1914 Ortega publishes his first book: Meditations of Don Quixote, ${ }^{51}$ in whose prologue (entitled "Reader") indicates that "under the title of Meditations, this first volume announces essays of varying lessons ${ }^{\prime \prime 2}$. It is still curious that in the prologue to Ideas for a biological conception of the world of Uexküll, our philosopher indicates that the content of this text are meditations: "I must declare that these biological meditations have exerted great influence since $1913^{53 "}$. That is, what Ortega presents in his book and what he finds in Uexküll is an analogous thinking, a reflection on some concrete things. In principle, the Quijote Meditations had to have been the first volume of a series of four meditations, although he never wrote the other three. In these Meditations, the last issue is the Spanish circumstances, since, as we know, Ortega's project at that time was the Spanish regeneration and the overcoming of secular backwardness.

The text begins by talking about love, intellectual love, and seems to be inspired by Scheler ${ }^{54}$, in defining philosophy as the general science of love; Moreover, these "Meditations $\mathrm{n}$ or are philosophy, which is science. They are simply rehearsals. And the essay is science, except the explicit test" ${ }^{\prime \prime 5}$. The book, he says explicitly, is not a work of philosophy, although, the findings he now presents, will be claimed as precedents of the works of other authors many years later, so, at least the prologue and the Preliminary Meditation, must be considered as philosophical texts and with it, both the "circumstance", the cornerstone of his philosophy, and the "perspective", will

\section{Op cit, p. 141.}

50 Marías J Introduction to philosophy, Revista de Occidente, Madrid, 1967, page 53 says that the circumstance is everything that surrounds us "from my body to the farthest nebula" With this conception - which I think does not coincide with that of Ortega - it is reasonable that I see her present both in Adam in paradise, and in Vejamen of the speaker.

51 Ortega Y Gasset J, 1914, Meditations of Don Quixote, OC I, p. 747-825.

52 Op cit, p. 747.

53 Ortega Y Gasset J, 1934, Foreword to the second edition of Ideas for a biological conception of the world by Jacob von Uexküll, Editorial Espasa Calpe, Madrid, p. 2.

54 Although a further reference is possible: Plato. The theme of love is found both in the Banquet and in the first speeches of the Fedro.

55 Ortega Y Gasseet J, 1914, Meditations of Don Quixote, Op cit, p. 753. 


\section{Philosophy International Journal}

be inscribed in the philosophical world.

The Meditations speak of great matters, such as the different literary genres, although it does not forget the small matters. It takes care of the landscape ${ }^{56}$ Spanish, which as it is usually read refers to the Hispanic cultural world and also speaks "of the small issues where the intimacy of a race is revealed"57 And he adds shortly thereafter: "Man yields the maximum of his capacity when he becomes fully aware of his circumstances. By them communicates with the universe"58. That's why Rábade ${ }^{59}$ thus understands circumstances such as the material and social contour, and whatever "circumstance" could be read as "what surrounds us", we should give, at this time of reading, the reason for Rábade.

That's why Ferrater too ${ }^{60}$ says that man sees the world through circumstance and not sub specie aeternitatis. Ortega himself indicates that circumstance is circum-stantia, a term that was not new in Ortega, he had used it in 1912 in an unpublished article about Baroja, ${ }^{61}$ in which, speaking of poetry, he opposed "life" to "circumstance." This article, little named by Ortega scholars, defends an aesthetic similar to that of Adam in paradise, indicating that in 1912 he had not yet overcome Cohen's idealism.

In the text at hand, Ortega clearly defines the "circumstance": "The circumstance! Circum-stantia! Things ${ }^{62}$ molts that are around us!"63 and continues: "Very close, very close to us, they raise their tacit physiognomies with a gesture of humanity and longing, as if we need to accept their offering and at the same time ashamed of the apparent simplicity of

56 As I noted above, "landscape" for Ortega, amounts to circumstance and therefore, to Umwelt.

57 Op cit, p. 754.

58 Ibidem

59 Rábade S Op cit, p. 91.

60 Ferrater Mora J The philosophy of Ortega y Gasset, Op cit, p. 31.

61 Ortega Y Gasset J, 1912, Variations on circum-stance , OC VII, p. 295306.

62 The word "thing" is very ambiguous. In the first definition according to the Dictionary of the Royal Academy of the Spanish Language, it is what has entity, or inanimate object, but also subject, subject, business or substance of considerable value. According to the dictionary of the use of Spanish, something is equivalent in ordinary language to what in philosophical language it would be to be or entity, or, object that exists outside the mind. Ferrater Mora's philosophy dictionary indicates that an individual material entity is considered something. In accordance with all this, we can think that in this text, something designates an individual entity and material of an extramental nature. Ortega in Adam in Paradise, Op cit, page 66 writes: "Everything is a crossroads in his life, his being is the set of relationships, of mutual influences in which all others are found. A stone at the edge of the road needs to exist from the rest of the universe", although it is possible that in 1914 he was no longer satisfied with this statement, he does not correct it in the 1916 edition.

63 Ortega Y Gasset J, 1914, Meditations of Don Quixote, Op cit, p. 754. their donation"64. The circumstance, Umwelt, "surrounding world" is made up of those things that are offered to us ${ }^{65}$, our perceptive world, Merkwelt, in the language of Uexküll. Those things that are "around us", very close to us, "very close," says Ortega. It is not the entire world of Adam in Paradise, nor of the speaker's Vejamen, on the contrary, it is this little world that surrounds us and, through which, we communicate with the universe.

Uexküll says: "The sum of these stimuli forms the surrounding world of the animal" ${ }^{16}$. The animal, man, receives the stimuli of the things that are around him and thereby builds his perceptual world. Man has a perceptual world that coincides with his world of actions, both are the Umwelt, the "circumstance" of man, what we can know, our bridge with the Universe ${ }^{67}$. Ortega says that the individual life, the immediate, the circumstance are names of the same thing: "those portions of life from which the spirit that encloses, its logos has not been extracted" ${ }^{\prime \prime}$, that is, life not interpreted, life prior to culture. The circumstance is "everything individual, immediate and circumstantial"69. Individual life is linked to its "surrounding world." There is a clear biological matrix here, the Umwelt of Uexküll, which Ortega must fill in to clarify his conception of the individual human being who is not just a living being, is a being with his circumstance, as opposed to idealistic individualism ${ }^{70}$. As Uexküll writes: "If

\section{Ibidem}

65 The living, according to Uexküll, builds his own Umwelt. For Ortega the Umwelt is the circumstance and this is built by the Self. In Adam in paradise, the world is an interpretation, a construction of man. In discussing the perspective, in the next chapter, I will discuss this Orteguian constructivism. If the world is built by each man, each individual builds his circumstance.

66 von Uexküll J Bausteine, p. 31.

67 As I pointed out, Uexküll indicates that the living receives the notes of the objects that surround him. The living, built according to a plan, has a structure such that each and every one of its parts harmonize with each other. Consequently the receptors - sense organs - have a structure that depends on the general structure of the living. And according to this structure, it can capture some stimuli and does not capture other stimuli because its receptors cannot, by their structure, capture them. These stimuli will be beneficial or harmful. They, through the nervous system, reach the central organ and through the schemes, on the one hand they produce the image of the world and on the other hand, they generate the answers. A cat has a sensory structure different from man. It can live in the same physical space, but it has its own world different from the human one. The structure of our sensory receptors, together with our psychic state, captures a section of the total worldly stimuli (Ortega will use years later, the image of the sieve or reticle) and with it, like the cat or the starfish, we build our world. Uexküll says that the animal and its world form a unity. Ortega translates "surrounding world" by circumstance and therefore can say, completely according to Uexküll, that "I am me and my circumstance", that is, my I-one is formed by my biological self and my surrounding world, like the Cat is made up of the biological cat and the cat's own surrounding world.

68 Ortega Y Gasset J, Op cit, p. 755.

69 Ibidem.

70 I think that writing this work, Ortega is in full tr to Transit from idealism to the phenomenology, which leads to that while on the one hand, 


\section{Philosophy International Journal}

you want to embrace the world of effects and the perceptual world with the name of the surrounding world, it may well be done; but one must take into account at once that the two together do not result in any unity, but for that the organism of the animal is essential, which is the one that creates the dependence between both worlds" ${ }^{\prime 11}$. That is why Ortega can affirm: "I am me and my circumstance" ${ }^{\prime \prime 2}$. And note that it speaks of "my circumstance," in the singular, "my own world, my surrounding world"73.

Heredia $^{74}$ says that Uexküll with the Umwelt raises the existence of a world of its own that is different from the world of human perception and in turn, different from Welt, world or universe of science. For Ortega, the circumstance is different from the universe, designated as Welt, since it says that through it we communicate with the universe, which implies that "circumstance" and "universe" are concepts of different content. The "circumstance" is contained in the "universe", although it is not confused with it. This brings us to a point that I think is worth considering. The "circumstance", like the Umwelt, are places, moles, with which we disagree with the proposals of P. Cerezo ${ }^{75}$ which considers that the "circumstance" comes from the Um-gebung of Husserl and not from the Umwelt of Uexküll. And as a consequence, the "circumstance" does not have a geographical character. To confirm its geographical character, that it is a place, we must read Ortega: "And we march among them blind to them" $"$ "The quotation is the continuation of the aforementioned "silent things". Even more blunt, and totally in the orbit of Uexküll, is the following fragment: "My natural exit to the Universe opens through the ports of the Guadarrama or the Ontígola field. This sector of surrounding reality forms the other half of my person; only through him can I integrate and be fully myself"'77. We can compare it with a paragraph from Von Uexküll: "The normal perceptual world of man in free Nature shows him a field of effects limited all around the horizon.

\footnotetext{
there are texts constructivist, as noted in the next chapter, they coexist with phenomenological texts, as San Martín has repeatedly pointed out, especially in Ortega's phenomenology.

71 von Uexküll J, Bausteine, p. 53.

72 Ortega Y Gasset J, Op cit, p. 757.

73 Iriarte (Ortega y Gasset, his person and his work, Op cit, page 160 and $160 \mathrm{n})$ indicates that Ortega gave the phrase a metaphysical scope. In the footnote, he considers that the cited expression has a very restricted value and lacks metaphysical value. From what I have stated, I should consider that I agree with Iriarte at this point: the circumstance is a mole, a place, although, later, after 1929, it acquires a metaphysical character. Iriarte considers that with this phrase he anticipates Heidegger's Dasein.

74 Heredia JM Jakob von Uexküll, spokesman for an unknown world, $O p$ cit, p. 22.

75 Cerezo P, Op cit, p. 226.

76 Ortega J, and Gasset $O p$ cit, p. 754.

77 Ortega J, and Gasset $O p$ cit, p. 756.
}

This horizon will be rare that is beyond six hours of road, ${ }^{78}$ adding also: "Therefore, man can in one day reach that limit and return from it. The territory closed by the horizon is its homeland, which you can travel on foot in its entirety without having to spend the night outside it"779. Both texts are parallel and show us that the "circumstance" has a geographical character, which, at least in Meditations, is a mole ${ }^{80}$. Below we will see how this geographical character is lost, although when Ortega uses the term "landscape" as a substitute for "circumstance" it is maintaining its geographical aspect.

Ramirez ${ }^{81}$ criticizes the expression "I am me and my circumstance. "However, what is most interesting about Ramírez's study is his quote from Izquierdo ${ }^{82}$, carried out in a critical tone, which recognizes that the formula "I am me and my circumstance" is a simple tracing of the biological law discovered at that time, according to which the organism and its environment adapt mutually ${ }^{83}$. That is, it recognizes the influence, not quoted, of von Uexküll. Notes that, in Quijote Meditations, following a fragment of a purely biological character- "The most recent biological science studies the living organism as a compound unit of the body and its particular environment; so that the vital process consists not only in the adaptation of the body to its environment, but also in the adaptation of the medium to its body, , $^{84}$ appearing below the formula "I am me and my circumstance" 85 , which shows both its biological character and the possible relationship of the "circumstance" with the work of Uexküll, not cited by Izquierdo. However, the author adds: "But it is not a discovery of Ortega, which also does not seem to have realized perfectly its philosophical value, until fifteen or sixteen years later"86. As we will see below, the circumstance is little used by Ortega until he reads Heidegger, so we can agree with Ramirez and Izquierdo. That, in a footnote, says that the statement "I am me and my circumstance" is the axis of all Orteguian reflections after $1929^{87}$.

Mary ${ }^{88}$ seems to give an answer to Ramírez's criticism. For Ortega's disciple, life is the self and the things - that make

\footnotetext{
78 von Uexküll J Bausteine, p. 116.

79 Ibide,

80 I have not found any commentator that takes this claim into consideration. This is especially curious in Marías who knew Uexküll widely and could have observed the parallelism of both texts cited.

81 Ramírez S, The philosophy of Ortega y Gasset, Op cit, p. 249.

82 Left Spanish Philosophy, Editorial Argos, Madrid, 1935, p. 60-61.

83 Ramírez S, Op cit, p. 193.

84 Ortega Y Gasset J, 1914, Quijote Meditations, Op cit, p. 750-751.

85 Op cit, p. 751.

86 Ramírez S, Op cit, Ibidem.

87 Ibidem.

88 Marías J, About Ortega, Revista de Occidente, Madrid, 1971, p. 27.
} 


\section{Philosophy International Journal}

up the circumstance - but it is not a sum of two elements, and he adds: "These are two abstract moments of the only effective and concrete reality that is life ${ }^{\prime \prime 89}$. I think that Marías, in 1971, reworked Ortega's thinking in making this statement. To live, for Ortega after 1928, will be to meet in the world and have to face the circumstances, however, in 1914 the Orteguian conception of "circumstance" is ontological, not vital, so I cannot agree with the reading that Marías does of Ortega.

This author, as I have already indicated, rejects the influence of Uexküll and Husser $l^{90}$. However, as we have seen, in Meditations, the "circumstance" arises from a biological matrix of Von Uexküll, the Umwelt, against the opinion of Marias. Now, we know that our philosopher read Husserl and that in 1913 he shows an inclination towards his philosophy ${ }^{91}$. Can we consider that there is any trace of Husserl in the concept of circumstance? P. Cherry ${ }^{92}$, as we have seen, it also derives the concept of "circumstance", not from the Umwelt, but from Um-gebung, from Husserl. Considering the importance of the subject, we must consider what Husserl says about it. Thus, speaking of nature, of the world in a natural attitude, writes the German author: "To this world, the world in which I find myself and which is at the same time my surrounding world, refers, then, to the complexes of the multiple and changing spontaneities of my consciousness (...) of theorizing consciousness in its various forms and degrees ${ }^{\prime \prime 9}$. This world is persistently for me in front of me', I am a member of it myself, but it is not for me there as a mere world of things but, in the same immediate way, as a world of values and goods, a practical world"'s4. The quotes show us that he doesn't really talk about a surrounding world, he talks about the "reality for me", how, in a natural attitude, Husserl finds the "world there before me", how the world gives me, the reality present in front of $\mathrm{me}^{95}$. Unlike Ortega, it is not him and the world "before me", but he himself is in the world, so he cannot say the famous "I am me and my circumstance ${ }^{\prime 96}$ for this, "I", the second "I", must be different from the circumstance, something that does not happen in Husserl: the conscious I is in that world around him, while in Ortega, the I, physical and psychic, he is in front of his circumstance and that I, physical and psychic

\section{Ibidem.}

90 Marías J, Notes to the edition of Quijote Meditations, op cit, p. 62-65.

91 This is reflected in two publications: Sensation, construction and intuition and in On the concept of sensation, as I have explained in the first part.

92 Cerezo P, Op cit, p. 226.

93 Husserl E, Ideas concerning a phenomenology and a phenomenological philosophy. Op cit, § 28, p. 66.

94 Husserl E, OP cit, § 27, p. 66.

95 Ortega gets closer to Husserl's conception by speaking, in Themes of the Escorial, of landscape. See below.

96 Ortega J and Gasset Op cit, p. 757. together with his circumstance, composes the total I. And, as P. Cerezo says ${ }^{97}$, Ortega understands his relationship with the circumstance as the reabsorption of it and his salvation, how to seek the meaning of what surrounds us, it is difficult to see how this is possible if the Self is a part of that world. Husserl himself, somewhat later, writes: "I find the 'reality' - it is what the word already means - as being there before ${ }^{\prime 98}$. That is to say, what I am given, as it is given to me, what is "there ahead" is not the "circumstance", fragment of reality, it is reality as it is, as it is given to me in a natural attitude A reality, a practical world, of goods and values, very different from the "circumstance" composed of "dumb things", from which the logos have not come off. Another fundamental difference is that the Orteguian circumstance is constructed and that of Husserl is given. Although, as we will see later, in the evolution of the concept "circumstance" there is, in its content, an approximation to Husserl's proposal.

"Dumb things" must be saved, full of meaning. "I am me and my circumstance, and if I don't save her, I don't save myself"99. It's not about "saving appearances," it's about applying intellectual love to those things that claim our attention, whether big or small ${ }^{100}$, as Ortega tells us to "seek the meaning of our surroundings" ${ }^{\prime \prime 01}$. If there is any doubt about the orteguian use of the Uexküll biological matrices, it is enough for us to read what our author writes after the aforementioned quotation from the ports of the Guadarrama: "The most recent biological science studies the living organism as a unit composed of body and its particular environment, so that the vital process consists not only in an adaptation of the body to its environment, but also in the adaptation of the environment to its body"102. Regardless of how authors like Marías read $\mathrm{it}^{103}$, these lines are not an analogy, nor an illustration. They are in the same paragraph that speaks of

\footnotetext{
97 Cerezo P, Op cit, p. 228.

98 EHusserl E, Op cit, §30, p. 69.

99 Ortega Y Gasset J, Op cit, p. 757.
}

100 Most authors consider that "saving" amounts to making sense. Make sense of things in my circumstance is not only giving them sen Tido, through culture, to them, is give me sense myself, for they are the other half of myself. This idea of "salvation" is implicit in Uexküll: if the living and its environment form a unity, the destruction of the "surrounding world" leads to the destruction of the animal, which is fully adapted to it. Consequently "if I don't save them, I don't save myself," is a statement that emerges from Uexküll's biological matrix. Salvation is realized by extracting the logos, according to Ortega. And this through culture, which, at this time, sees as opposed to spontaneous life.

101 Op cit, p. 757.

102 Op cit, p. 756-757.

103 Marías, Ortega, circumstance and vocation, Op. Cit, p. 156 indicates that this quotation is only a marginal reference, obviously an allusion to Uexküll, there being no more biological references in the theory of circumstance. And it is so marginal that it only adduces the example of man - the hand and the object adapt mutuall. 
"this sector of the surrounding reality" and just before the affirmation of "I am me and my circumstance". Strange place for analogies or illustrations that, if that is the case, do not illustrate but confuse.
It is true that, as we shall see, Ortega's notion of "circumstance" evolves, but it does not seem that in 1914 he has any relationship with Husserl. 